УДК 347.5

DOI https://doi.org/10.51989/NUL.2021.4.6

\title{
УМОВИ ПРИТЯГНЕННЯ ОСІБ, ВИННИХ У ДОВЕДЕННІ ДО БАНКРУТСТВА, ДО СУБСИДІАРНОЇ ВІДПОВІДАЛЬНОСТІ
}

\author{
Марченко Олеся Володимирівна, \\ доктор юридичних наук, \\ доцент кафедри цивільного, трудового та господарського права \\ Дніпровського національного університету імені Олеся Гончара \\ Вознюк Олег Ігорович, \\ студент юридичного факультету \\ Дніпровського національного університету імені Олеся Гончара
}

Стаття присвячена дослідженню проблемних аспектів та особливостей правового регулювання та застосування субсидіарної відповідальності, а саме: умов притягнення осіб, винних у доведенні до банкрутства суб'єктів господарювання - юридичних осіб, до субсидіарної відповідальності відповідно норм Кодексу України з процедур банкрутства (далі - Кодекс). Крім того, автор торкається питання щодо розуміння субсидіарної відповідальності як окремого господарсько-правового виду відповідальності, який покладається на засновників (учасників, акціонерів) або інших осіб, включно з керівником боржника. У статті також опрацьовано сутність та особливості мети субсидіарної відповідальності за доведення до банкрутства. Також було проаналізовано правове регулювання інституту субсидіарної відповідальності з урахуванням законодавчих змін, а саме заміна Закону України «Про відновлення платоспроможності боржника або визнання його банкрутом» новим нормативно-правовим актом Кодексом. 3 урахуванням позицій науковців та суддів господарських судів, було виділено і наведено основні переваги та недоліки законодавства про банкрутство. Ще одним пунктом нашої мети було питання доведення відсутності своєї вини, законодавцем покладене на особу, яку притягують до субсидіарної відповідальності, у зв'язку з чим саме вона повинна довести відсутність у своїх діях складу делікту. У статті розкрито сутність форми звернення до господарського суду для покладення на особу субсидіарної відповідальності, які в Кодексі, на жаль, не визначені. Авторами чітко зазначені умови, ознаки та підстави для застосування субсидіарної відповідальності за доведення до банкрутства, а також дії ліквідатора щодо доведення необхідності застосування додаткової відповідальності до винних осіб. Визначено, що субсидіарні вимоги є частиною ліквідаційної маси і не можуть бути отримані кредиторами іншим чином, ніж у порядку черговості у процедурі банкрутства.

Ключові слова: банкрутство, неплатоспроможність, боржник, ліквідатор, субсидіарна відповідальність, доведення до банкрутства.

\section{Marchenko Olesia, Vozniuk Oleh. Conditions of bringing persons guilty of banrutcy to subsidiary liability}

This article is devoted to the study of problematic aspects and features of legal regulation and application of subsidiary liability, namely: the conditions for bringing persons guilty of bankruptcy of business entities - legal entities, to subsidiary liability in accordance with the Code of Ukraine on Bankruptcy Procedures (hereinafter - the Code). In addition, the author addresses the issue of understanding subsidiary liability as a separate commercial and legal type of liability imposed on the founders (participants, shareholders) or other persons, including the head of the debtor. The article also elaborates the essence and features of the purpose of subsidiary liability for bankruptcy. At the same time, the legal regulation of the institution of subsidiary liability was analyzed taking into account legislative changes, namely the replacement of the Law of Ukraine "On Restoration of Debtor's Solvency or Recognition of Bankruptcy" with a new legal act of the Bankruptcy Procedure Code (hereinafter - the Code). Taking into account the positions of scholars and judges of commercial courts, the main advantages and disadvantages of bankruptcy law were identified and presented. Another point of our goal was the issue of proving the absence of guilt by the legislator, entrusted to the person who is brought to subsidiary responsibility 
and it is he who must prove the absence in his actions of tort. The article reveals the essence of the form of appeal to the commercial court to impose subsidiary liability on a person, which are unfortunately not defined in the Code. The authors clearly state the conditions, features and grounds for the application of subsidiary liability for bringing to bankruptcy, as well as the actions of the liquidator to prove the need for additional liability to the perpetrators. It is determined that the subsidiary claims are part of the liquidation estate and cannot be obtained by creditors other than in the order of priority in the bankruptcy procedure.

Key words: bankruptcy, insolvency, debtor, liquidator, subsidiary liability, bankruptcy.

Постановка проблеми. Проблема правового регулювання, притягнення осіб до субсидіарної відповідальності у випадку банкрутства юридичної особи, займає зараз одне із основних місць у дослідженнях науковців, оскільки після прийняття Кодексу України з процедур банкрутства (далі - Кодекс), вона $\epsilon$ основним методом забезпечення виконання зобов'язань перед кредиторам у господарсько-правових відносинах. Особливостями субсидіарної відповідальності, з огляду на Кодекс, $\epsilon$ посилення ії запобіжної та компенсаційної функції в інтересах кредиторів боржника. Однією із головних функції субсидіарної відповідальності при ліквідації банкрута $\epsilon$ виключення втрат кредиторів неплатоспроможної юридичної особи внаслідок дій (бездіяльності) його засновників, учасників, керівників або інших осіб.

Стан дослідження. Комплексних досліджень умов притягнення осіб, винних у доведенні до банкрутства, до субсидіарної відповідальності, на жаль, немає, оскільки Кодекс $\epsilon$ досить новим нормативним актом. Проте окремі аспекти даної проблеми у своїх працях досліджували, в першу чергу, такі судді Касаційного господарського суду, як С.В. Жуков, П.Д. Пригуза, та науковці А.П. Довгань, Д.В. Катречко, В.Я. Погребняк та інші.

Мета статті - дослідження умов притягнення осіб, винних у доведенні до банкрутства, до субсидіарної відповідальності, визначення основних аспектів реалізації субсидіарної відповідальності.

Виклад основного матеріалу. Субсидіарна відповідальність за доведення до банкрутства $\epsilon$ новелою законодавства, яку запроваджено в юридичний обіг з початку 2018 р. у зв'язку з прийняттям Кодексу. Цим нормативно-правовим актом встановлено, що метою відповідальності $€$ притягнення винних у доведенні до банкрутства осіб до додаткової (субсидіарної) відповідальності і стягнення на користь креди- торів боржника непогашених у ліквідації кредиторських вимог. Іншими словами, це додатковий спосіб погашення боргів перед кредиторами завдяки покладенню на винних осіб відповідальності у вчиненні неправомірних дій.

При підготовці Кодексу українські законодавці використали неоціненний досвід як американської судової практики, так і європейської. На початку XX ст. в США виникає та отримує у подальшому широке застосування доктрина «зняття корпоративної вуалі». Ії̈ сутність полягає у тому, що з метою захисту добросовісного кредитора при певних обставинах обмежена відповідальність юридичної особи іґнорується, а збитки, спричинені процедурою ліквідації, стягується з реальних власників бізнесу. Ці дії використовувалися для отримання, виведення і переведення активів на іншу особу, ухиляння від сплати податків або шахрайства з метою збагачення. Чітких параметрів ця доктрина не дала, тому на сьогодні вирішення подібних справ в американських судах відбувається відповідно до критеріїв власного переконання [1. с. 97-98].

Якщо звернутись до європейської практики, то окрему увагу необхідно звернути на те, що 11 грудня 2018 р. було прийнято постанову Великої палати Європейського суду з прав людини у справі Лекич проти Словенії, в якій чітко зазначено, що засновник і директор фірми, яка була виключена з державного реєстру без проведення ліквідаційної процедури, притягуються до відповідальності за порушення статті 1 Протоколу № 1 Конвенції про захист прав людини і основоположних свобод проти власності. ЄСПЛ визнав, що директор як особа найбільш наближена до контролю за юридичною особою повинен був знати про те, що компанія не пройшла процедуру банкрутства, і через це передбачити можливі наслідки для директора та засновника у вигляді субсидіарної 
відповідальності. Директор і засновник знали про негативні фінансові результати діяльності компанії, але не вжили заходів щодо визначення компанії банкрутом у рамках процедури неспроможності, фактично продовживши їі існування як юридичної особи, незважаючи на неможливість виконання зобов'язань [2].

Зазначене вище положення Конвенції врахували українські законодавці, встановивши ч. 2 ст. 61 Кодексу, що «під час здійснення своїх повноважень ліквідатор має право заявити вимоги до третіх осіб, які відповідно до законодавства несуть субсидіарну відповідальність за зобов'язаннями боржника у зв'язку з доведенням його до банкрутства. Розмір зазначених вимог визначається 3 різниці між сумою вимог кредиторів і ліквідаційною масою. У разі банкрутства боржника з вини його засновників (учасників, акціонерів) або інших осіб, у тому числі з вини керівника боржника, які мають право давати обов'язкові для боржника вказівки чи мають змогу іншим чином визначати його дії, на засновників (учасників, акціонерів) боржника - юридичної особи або інших осіб у разі недостатності майна боржника може бути покладена субсидіарна відповідальність за його зобов'язаннями. Стягнені суми включаються до складу ліквідаційної маси і можуть бути використані лише для задоволення вимог кредиторів у порядку черговості» [3].

Введення в дію Кодексу було відтерміновано до 21 жовтня 2019 р., але з цієї дати для кредиторів з'явилася нова можливість задовольнити свої вимоги у процедурі банкрутства шляхом застосування до керівника боржника субсидіарної відповідальності. Таким чином, субсидіарна відповідальність у справах про банкрутство - це самостійний господарсько-правовий вид відповідальності, який покладається на засновників (учасників, акціонерів) або інших осіб, причетних до банкрута, включно з керівником боржника, за наявності підтвердження вини вказаних осіб юридичної особи (боржника у справі про банкрутство) при доведенні до стану неплатоспроможності. Доказом того, що законодавство не пов'язує можливість покладення субсидіарної відповідальності в порядку ч. 5 ст. 41 Закону
України «Про відновлення платоспроможності боржника або визнання його банкрутом» на третіх осіб за наявністю вироку у кримінальній справі щодо таких осіб про встановлення в їхніх діях (бездіяльності) складу кримінального правопорушення, оскільки в даному випадку особи з огляду на спеціальний припис притягуються до відповідальності у формі солідарної відповідальності (аналогічний висновок про застосування норм права викладений у постанові Верховного Суду від 9 жовтня 2019 р. по справі № 910/21232/16) [4].

Притаманною ознакою цього виду відповідальності $\epsilon$ те, що особа, яка $\epsilon$ відповідачем, повинна довести відсутність своєї вини. Після визнання боржника банкрутом, за наявності ознак доведення до банкрутства юридичної особи-боржника, погашення заборгованості банкрута $\epsilon$ неможливим внаслідок дій та (або) бездіяльності засновників (учасників, акціонерів) або інших осіб, зокрема й керівника боржника, які мають право давати обов'язкові для боржника вказівки чи мають змогу іншим чином визначати його дії, допоки такі особи не доведуть протилежного [1, с. 103-104].

Суб'єктами притягнення до субсидіарної відповідальності у справах про банкрутство, відповідно до статті 61 Кодексу $\epsilon$ засновники, учасники, акціонери та інші особи, зокрема керівники боржника. Коли згадуються «інші особи», йдеться про те, що притягненими до відповідальності також можуть бути власники майна (орган, уповноважений управляти майном) боржника або головний бухгалтер. А через те, що в українському законодавстві відсутній вичерпний перелік цих суб'єктів, це призводить до того, що господарські суди самостійно визначають належність певних осіб до суб'єктів субсидіарної відповідальності за доведення до банкрутства.

Окрему увагу слід приділити тому факту, що форми звернення до суду для притягнення до субсидіарної відповідальності у Кодексі не визначені. Встановлено, що ці дії повинні відбуватися виключно у процесі ліквідаційної процедури, тому що пред'явити вимоги до суб'єктів субсидіарної відповідальності можна лише після того, як ліквідатор вчинив усі дії з виявлення та реалізації активів боржника. 
У ліквідатора за наявності обставин доведення до банкрутства боржника виникає право на пред'явлення вимоги щодо субсидіарної відповідальності до осіб, винних у скоєнні даних деліктів, якщо в результаті реалізації активів грошових коштів виявиться недостатньо для задоволення потреб кредиторів. Відповідно до Постанови Верховного Суду від 17 червня 2020 р. у справі № 923/590/18, можливість звернення до суду з метою покладення субсидіарної відповідальності $\epsilon$ винятково у ліквідатора банкрута [5]. На думку авторів, це положення ставить у невигідне становище кредиторів, які не мають права звертатися з подібними заявами, що не відповідає інтересам захисту прав кредиторів.

Наступним проблемним аспектом захисту прав і законних інтересів суб'єктів у процедурі банкрутства $\epsilon$ зобов'язання, які виникають внаслідок вчиненої шкоди, яка була завдана банкруту ще до відкриття процедури ліквідації.

На відміну від кримінального та адміністративного законодавства, де чітко визначена диспозиція доведення юридичної особи до банкрутства, норми Кодексу хоча і містять диспозицію (зміст) правопорушення - «доведення до банкрутства», за яке передбачена санкція у вигляді субсидіарної відповідальності, проте не конкретизують дії цієї відповідальності, за наявності яких особа може бути притягнута до відповідальності.

Слід звернути увагу: практика Верховного Суду вказує на те, що об'єктивну сторону такого делікту становлять дії або бездіяльність певних фізичних осіб, пов'язаних із боржником, що призвели до відсутності у нього майнових активів для задоволення вимог кредиторів. При розгляді цих питань щодо обставин, які мають бути доведені ліквідатором та, відповідно, підлягають встановленню судом для притягнення до субсидіарної відповідальності, мають братися до уваги також деякі позиції статті 215 Господарського кодексу України (далі - ГКУ) та підстави для порушення справи про банкрутство, з огляду на які такими діями можуть бути:

1) вчинення суб'єктами відповідальності будь-яких дій, направлених на набуття майна, за відсутності активів для розрахунку за набуте майно чи збільшення кре- диторської заборгованості боржника без наміру ії̈ погашення;

2) прийняття суб'єктами відповідальності рішення при виведенні активів боржника, внаслідок чого настала неплатоспроможність боржника за іншими його зобов'язаннями;

3) прийняття суб'єктами відповідальності рішення, вказівок на вчинення майнових дій чи бездіяльності боржника щодо захисту власних майнових інтересів юридичної особи боржника на користь інших юридичних осіб, що мало наслідком настання неплатоспроможності боржника [8].

Окремо слід зазначити, що Верховний Суд у постановах Великої Палати, прийнятих після введення дію Кодексу, визначає важливість врахування ризиків господарської діяльності (стаття 42 ГКУ) при наданні оцінки діям/бездіяльності суб'єктів відповідальності (відповідно до наведених моделей) на предмет покладення на них субсидіарної відповідальності.

Тим не менш, слід зазначити, що одноманітності думок стосовно цих питань немає, зокрема, можна стверджувати: «відсутність у матеріалах справи висновку про доведення до банкрутства боржника третіми особами не може бути беззаперечною підставою для звільнення їх від субсидіарної відповідальності» [9].

Обов'язковою умовою субсидіарних вимог $\epsilon$ те, що вони стягуються лише у випадках доведення юридичної особи до банкрутства. Інших підстав для притягнення до відповідальності Кодекс не визначає.

Заслуговує на увагу позиція судді Касаційного господарського суду П. Пригузи щодо підстав, обставин та строків подання позовної заяви за зобов'язання банкрута. Він зазначає, що таку позовну заяву «... слід подавати негайно після встановлення різниці між сумою вимог кредиторів і вартістю ліквідаційної маси. Негайне відкриття справи щодо субсидіарної відповідальності дасть можливість якомога раніше застосувати заходи забезпечення позову ліквідатора шляхом накладення арешту на майно відповідачів, винних у доведенні до банкрутства. Ця обставина буде спонукальним фактором (ефектом) для відповідачів до вирішення (розв'язання) ними питань заборгованості, в тому числі й через 
укладання мирової угоди, що також $\epsilon$ бажаним результатом при здійсненні ліквідаційної процедури: сторони можуть досягнути згоди про врегулювання спору на підставі взаємних поступок з урахуванням прав та охоронюваних законом інтересів учасників справи (скорочення строків провадження, прощення частини боргу, відстрочення, розстрочення, переводу боргу тощо) завершити провадження у справі» [1, с. 101-102].

Автори вважають, що при застосування такого підходу досить складно визначити реальний розмір збитків, який підлягає стягненню при субсидіарній відповідальності, оскільки вартість наявної ліквідаційної маси $\epsilon$ динамічною (може змінитися протягом реалізації майна банкрута). Ймовірна ситуація, коли з осіб, притягнутих до субсидіарної відповідальності, суд може стягнути суму більшу, ніж різниця між вимогами кредиторів і вартістю ліквідаційної маси. У такому випадку будуть порушені права осіб, притягнутих до субсидіарної відповідальності. Коли ліквідатор звертається із заявою про покладення субсидіарної відповідальності після завершення реалізації об'єктів ліквідаційної маси та розрахунків з кредиторами, розмір, що підлягає стягненню з винних осіб, які притягуються до субсидіарної відповідальності, $\epsilon$ більш зрозумілим і передбачуваним.

Згідно Кодексу, ліквідатор для доведення необхідності застосування субсидіарної відповідальності до винних осіб може вчинити певні дії, а саме:

1) використання того, що у процедурі розпорядження майном розпорядник зобов'язаний проводити аналіз фінансовогосподарського стану боржника та виявляти (за наявності) ознаки доведення до банкрутства (ч. 3 ст. 44 Кодексу). Крім того, господарським судом може бути розглянуте питання виникнення загрози неплатоспроможності і роль осіб, винних у цьому;

2) у процедурі ліквідації ліквідатор має обов'язок аналізувати фінансовий стан банкрута (4. 1 ст. 61 Кодексу) [3] .

Аналіз фінансового становища банкрута у поєднанні з дослідженням ліквідатором підстав виникнення заборгованості боржника перед кредиторами у справі про банкрутство дозволяє виявити наявність чи відсутність дій засновників (учасників, акціонерів) або інших осіб, які були зазначені вище.

Притягнення осіб, винних у доведенні до банкрутства, до субсидіарної відповідальності, має відбуватися на підставі доведених фактів та документів, які були отримані у процедурі ліквідації боржника.

Доктор юридичних наук, суддя-спікер Касаційного господарського суду у складі Верховного Суду С.В. Жуков визначає, що під час доведення фактів, які свідчили би про певні дії або бездіяльність осіб, винних у банкрутстві юридичної особи, необхідно встановити такі дані:

1) наявність/відсутність документації з фінансово-господарської діяльності, податкових звітів, первинної документації, рішення керівників, органів управління та засновників;

2) наявність угод після відкриття процедури банкрутства, які були визнані недійсними відповідно до ст. 40 Кодексу;

3) наявність інформації про рух коштів за три роки до відкриття провадження і весь час після цього;

4) наявність інформації про активи і пасиви на момент відкриття справи;

5) визначення моменту, коли боржник став неплатоспроможним;

6) сума непогашених вимог за відсутності активів у ліквідаційній масі;

7) дія або бездіяльність, які призвели до неплатоспроможності боржника;

8) вина конкретної особи/осіб у доведенні до банкрутства [1, с. 104].

3 огляду на вказане ліквідатор здійснює дослідження причин і обставин справи, встановлює осіб, які винні у доведенні юридичної особи до банкрутства, а вже господарський суд встановлює, які дії або бездіяльність яких саме осіб призвели до доведення до неплатоспроможності боржника і причиннонаслідкові зв'язки між ними.

Для отримання доказів обґрунтування підстав для покладення субсидіарної відповідальності господарський суд може вчинити такі дії:

1) отримати безпосередньо від ліквідатора або від залученої ним спеціалізованої організації (спеціалістів) висновок (аудиторський висновок) про наявність ознак доведення до банкрутства; 
2) за певних умов залучити до участі у справі державний орган з питань банкрутства та зобов'язати його провести аналіз доведення боржника до банкрутства;

3) за ініціативою ліквідатора призначити бухгалтерську або економічну експертизу, на вирішення якої поставити питання наявності ознак доведення до банкрутства;

4) отримати від осіб, зацікавлених у підтвердженні своєї невинуватості в доведенні боржника до банкрутства, висновок (аудиторський висновок) про відсутність ознак доведення до банкрутства, який можуть скласти залучені ними спеціалісти $[7$, c. 11$]$.

Дії та/або бездіяльність суб'єктів у справах про доведення до банкрутства завжди відбуваються через вольові рішення та дії посадових осіб та власників, які притягуються до відповідачів у господарському процесі, під час розгляду позовних проваджень. Отже, факти, які ставляться у провину відповідачам при доведенні до банкрутства, $\epsilon$ негативними фактами, котрі доводять, що відповідачі своїми цілеспрямованими діями використали юридичну особу - боржника як інструмент для завдання шкоди кредиторам через банкрутство. Встановлення таких негативних фактів у процесі доказування у справі про банкрутство має юридичне значення для висновків суду про наявність чи відсутність доказів про підстави покладення відповідальності на певних осіб [6, с. 56].

Необхідно звернути увагу на те, що у справах про притягнення до субсидіарної відповідальності вина презюмується, а її відсутність повинна бути доведена відповідачем. Водночас суди під час вирішення питання щодо вини (виду вини) суб'єкта субсидіарної відповідальності виходять з обов'язків та повноважень суб'єктів відповідальності стосовно боржника, покладених на них законом та/або статутом, враховуючи при цьому положення ч. 1, 3 ст. 4 Кодексу [10].
Крім того, необхідно зазначити, що вимоги до третіх осіб, які несуть субсидіарну відповідальність за доведення боржника до банкрутства, $€$ частиною аналізу фінансового становища банкрута та вимагають вжиття всієї повноти заходів, спрямованих на виявлення активів боржника [3].

Оцінюючи викладене вище, потрібно зазначити, що розгляд ліквідатором питання про наявність чи відсутність підстав для подання заяви про покладення субсидіарної відповідальності, а також оцінка господарським судом таких дій ліквідатора обов'язково повинні бути відображені в ухвалі про затвердження звіту ліквідатора, ліквідаційного балансу [11].

Висновки. Таким чином, практика українського законодавства щодо притягнення осіб до субсидіарної відповідальності $€$ різноманітною та неузгодженою. Проведене дослідження виявило низку протиріч, які в обов'язковому порядку повинні бути уточнені та вирішені на законодавчому рівні для уніфікації судової практики з цього питання.

Для усунення виявлених колізій вважаємо за доцільне викласти ч. 2 ст. 61 Кодексу в наступній редакції: «Під час проведення ліквідаційної процедури ліквідатор та кредитори мають право заявляти вимоги до третіх осіб, які відповідно до законодавства несуть субсидіарну відповідальність за зобов'язаннями боржника у зв'язку з доведенням його до банкрутства».

Також бажано законодавчо закріпити строк, протягом якого ліквідатор має звертатися із заявою про покладення відповідальності. Можливим вирішенням проблеми може стати норма про те, що ліквідатор повинен звертатися із заявою про покладення субсидіарної відповідальності тільки після завершення реалізації об'єктів ліквідаційної маси та розрахунків з кредиторами. У цьому випадку розмір відшкодування, що підлягає стягненню з винних осіб, які притягуються до субсидіарної відповідальності, стає зрозумілим і передбачуваним.

\section{ЛITEPATУРА:}

1. Жуков С.В. Ліквідаційна процедура банкрутства юридичних осіб відповідно до Кодексу України з процедур банкрутства : наук.-практ. посібник. Київ : Алерта, 2021. 292 с.

2. Постанова ЄСПЛ від 14 лютого 2017 р. у справі «Лекич проти Словенії». URL: http:// base.garant.ru/71760252/ (дата звернення: 1 квітня 2021 р.) 
3. Кодекс України з процедур банкрутства : Закон України № 2597-VIII від 18 жовтня 2018 p. URL: https://zakon.rada.gov.ua/laws/show/2597-19\#n1255 (дата звернення: 1 квітня 2021 p.)

4. Про відновлення платоспроможності боржника або визнання його банкрутом: Закон України \{Закон втратив чинність на підставі Кодексу № 2597-VIII від 18 жовтня 2018 р.\}. URL: https://zakon.rada.gov.ua/laws/show/2343-12\#Text (дата звернення: 21 квітня 2021 р.)

5. Пригуза П.Д., Довгань А.П., Катречко Д.В. Умисне банкрутство: теорія і практика субсидіарної відповідальності. Херсон, 2020. 180 с.

6. Постанова Верховного Суду від 17 червня 2020 р. у справі № 923/590/18. URL: https://reyestr.court.gov.ua/Review/89957325 (дата звернення: 20.04.2021)

7. Пригуза П.Д., Довгань А.П., Катречко Д.В. Умисне банкрутство: теорія і практика субсидіарної відповідальності. Херсон, 2020. 180 с.

8. Постанова Верховного Суду від 17 червня 2020 р. у справі № 924/669/17. URL: https://reyestr.court.gov.ua/Review/90025224 (дата звернення: 14 квітня 2021 р.)

9. Господарський кодекс України: Закон України № 436-IV від 16 січня 2003 р. URL: https://zakon.rada.gov.ua/laws/show/436-15\#Text (дата звернення: 14 квітня 2021 р.)

10. Жуков Сергій. Шукаємо винних. Закон і бізнес. № 5, 8-14 лютого, с. 11. URL: https://zib.com.ua/ru/print/141324 (дата звернення: 1 квітня 2021 р.)

11. Постанова Верховного Суду від 10 грудня 2020 р. у справі № 922/1067/17. URL: https://reyestr.court.gov.ua/Review/93589364 (дата звернення: 1 квітня 2021 р.) 